\title{
SOURCES OF NEWS ABOUT MILITARY OPERATIONS AGAINST BOKO HARAM INSURGENTS IN NIGERIA NEWSPAPERS: A CONTENT ANALYSIS INVESTIGATION ${ }^{1}$
}

\author{
Ben-Collins Ndinojuo (a), Walter Ihejirika (b), Godwin Okon (c) \\ (a) University of Port Harcourt. Port Harcourt, Nigeria. Email: becoolholly[at]gmail.com \\ (b) University of Port Harcourt. Port Harcourt, Nigeria. Email: walter.ihejirika[at]uniport.edu.ng \\ (c) Rivers State University. Port Harcourt, Nigeria. Email: okonbus2[at]gmail.com
}

\begin{abstract}
Nigerian military has been battling Boko Haram insurgents since 2009 with mixed successes amid claims that Nigerian troops were reluctant to engage the terrorists because the media framed the group as winning the battle, therefore, this study investigated the sources of news about military operations against Boko Haram. The theories supporting this research were the Agenda Setting and Framing Theory. Using content analysis of four Nigerian dailies; Daily Trust, Premium Times, The Nation \& Vanguard, the research analysed sources of news about military operations against Boko Haram from 2014-2016. Findings revealed 185 stories with an average of 1.5 sources, most are identified by their full names, most stories are reported with sources from mainly one side of the divide without corroboration and the dominant sources were military sources. There was no factual basis supporting media bias against Nigerian newspapers, instead media reports were more in support of military positions.
\end{abstract}

\section{Keywords}

Nigeria; military; Boko Haram; sources; newspapers; media; press

This work is licensed under a Creative Commons «Attribution» 4.0 International License.

1 Organization whose activity is prohibited in the territory of the Russian Federation 


\section{ИСТОЧНИКИ НОВОСТЕЙ О ВОЕННЬХ ОПЕРАЦИЯХ ПРОТИВ БОЕВИКОВ «БОКО ХАРАМ» (ОРГАНИЗАЦИЯ, ДЕЯТЕЛЬНОСТЬ КОТОРОЙ ЗАПРЕЩЕНА НА ТЕРРИТОРИИ РФ) В НИГЕРИЙСКИХ ГАЗЕТАХ: КОНТЕНТ- АНАЛИЗ}

Ндиножуо Бен-Коллинс (a), Ихеджирика Вальтер (b), Окон Годвин (c)

(a) Университет Порт Харкорт. Порт Харкорт, Нигерия. Email: becoolholly[at]gmail.com

(b) Университет Порт Харкорт. Порт Харкорт, Нигерия. Email: walter.ihejirika[at]uniport.edu.ng

(c) Государственный университет Риверс. Порт Харкорт, Нигерия. Email: okonbus2[at]gmail.com

\section{Аннотация}

Нигерийские военные с неоднозначным успехом сражаются с членами «Боко Харам ${ }^{1}$ (организация, деятельность которой запрещена на территории РФ) с 2009 года на фоне заявлений о том, что нигерийские войска неохотно привлекают террористов, потому что СМИ сформировали образ группировки как победившей в борьбе; поэтому в данной работе были исследованы источники новостей о военных операциях против «Боко Харам» (организация, деятельность которой запрещена на территории РФ). Это исследование использует теорию установления повестки дня и теорию фреймов. С применением контент-анализа четырех нигерийских газет - Daily Trust, Premium Times, The Nation и Vanguard - были изучены источники новостей о военных операциях против «Боко Харам» (организация, деятельность которой запрещена на территории РФ) в 2014-2016 годах. Результаты поиска выявили 185 историй, в среднем опирающихся на 1,5 источника; большинство из них подписаны полными именами; большинство историй сообщается в основном односторонне, без подтверждения, и доминирующими были военные материалы. Не обнаружено фактической основы, подкрепляющей предубеждение СМИ относительно нигерийских газет; вместо этого сообщения в СМИ были больше в поддержку позиции военных.

\section{Ключевые слова}

Нигерия; военные силы; Боко Харам (организация, деятельность которой запрещена на территории РФ); источники; газеты; медиа; пресса

Это произведение доступно по лицензии Creative Commons «Attribution» («Атрибуция») 4.0 Всемирная

1 Общество, внесенное Совбезом ООН в 2014 г. в список террористических организаций. Прим. Ред 


\section{INTRODUCTION}

The act of news reporting requires the obligation to be truthful, accurate and reliable. This is best achieved in how stories are sourced and proper attribution of news sources when writing news. This means that sources must be credible and pass the reliability threshold where information they provide is verifiable by corroboration. News media are integral to media studies, during national crises or emergencies, researchers work to help news producers in making information valuable and helpful to the audience. The public want to be informed, they turn to news sources to know what is happening, and information help them understand what might happen. This scenario describes the situation in the North East of Nigeria where the Nigerian government has been battling the insurgent group Boko Haram since 2009 with varying degrees of success.

As media researchers, our role is to explore vagaries of the conflicts and try to make meaning out of our observation from available data with the hope that it would contribute to literature about the crises, and also create a better understanding to help government, policy makers and other international agencies involved in efforts to bring the conflict to an end. Thus, Nigeria and its war against terrorism in the North East is our focus in this paper especially how newspapers covering military operations against the group present their news sources in articles. This would give us an understanding of the relationship between the media and the military and how to improve relations when presenting military operations to the public. Journalism first obligation is to tell the truth, to achieve this truth; news sources are central ingredients that make up news integrity and reliability, there is an absolute unanimity on this among news readers. This truth entails having (or naming) news sources, corroborating the information before printing, and presenting the information as intended by the news source(s).

General Winant Sidle on the need for the creation of the Sidle Commission (1984) that came up with framework for the cooperation of the media and military during military operations by the United States Military asked, "How do we conduct military operations in a manner that safeguards the lives of our military and protects the security of the operation while keeping the American public informed through the media?" The Commission agreed that the military should not report about its own activities and it would be best the independent media do the reporting of the conduct of military activities so the public, congress and the press can make their own deductions from the news reports. The media achieves 
this using agenda setting and the framing narrative and the gate keeping function to limit (sensitive) information available to the public.

According to Lister (2001) democracy is a relatively new concept for African nations (including Nigeria whose current democracy started in 1999). Many African nations only recently emerged from oppressive regimes into democracies, and in yet many of the cases, the military men only discarded the uniform and continued their oppressions in civilian garbs and in some others, the rulers have remained in power in perpetuity changing the constitution as it suits them to continue. The case of Nigeria although not the worst in Africa has seen mainly former military officers or their relatives as president with the exception of former President Goodluck Jonathan (2010-2015) who inherited office with the demise of his predecessor. Until recently, most television and radio stations and many newspapers in Africa were government-owned and -controlled. There was little critical, independent reporting.

Journalists acted as the transmission belt to convey government's ideas and messages to its people and never the reverse. Democracy brought about friction between the government and the press due to its open nature meaning greater access to government information and resources; the military and secret police were the go to guys whenever the government need to clampdown on journalists or their organisations. Historically, the media and governments in Nigeria have endured tumultuous relationships mainly due to the occupational hazards of journalism; pressmen want to expose, government wants to conceal, hence the friction (Musa, 2013; Adebanwi, 2011, Odogwu, 1990).

During the height of the Boko Haram insurgency in 2014, the Nigerian military confiscated and destroyed some newspapers and the vans used to transport them across the country over allegations that intelligence reports revealed the newspapers were being used to move materials with grave security implications for Nigeria's military and capable of derailing the war against the Boko Haram insurgents (Abimboye, 2014; Abimboye \& Ibeh, 2014). What was however not clear was what constituted the threat to military operations in the North East; the newspaper contents or the vans transporting the newspapers.

This hostility was again observed when journalists with Premium Times, an online newspaper in Nigeria were arrested by the police following complaints by the Nigerian Army of the news organisation publishing damaging claims about military documents which "allegedly" led to deaths and loss of equipment, although where the deaths occurred or the equipment lost were not stated (Ibekwe, 2017; Ogundipe, 2017). The military in this case accused the journalists of working against government 
interest in the war against Boko Haram hence their arrest. This mirrors the actions of the military against newspapers in 2014 although the 2017 incident was limited to one media organisation; it however included a new dimension with the arrest of specific journalists working for an online newspaper.

This paper analyzed news stories about military operations against Boko Haram in the North East in Nigerian newspapers with the aim of identifying their news sources. This was imperative because according to the then Director of Information, Defense Headquarters, Major General John Enenche, Nigerian troops were reluctant in the past to engage the Boko Haram terrorists because the media framed the Boko Haram group as superior and winning the battle against the military making Nigerian soldiers hesitant to engage members of the sect in open battles (Erunke, 2017). This view however, is subjective; one of the ways it can be examined is by identifying the news sources contained in newspaper reports about military operations against Boko Haram insurgents, the idea being that if there are less military sources quoted and cited in reports, it increases the likelihood of media bias against the military. On the other hand, if there are more of military sources, it reduces the likelihood of media bias as the military is not expected to speak bad about their own organisation. The study provided answers to the following research questions:

1. What is the average number of sources observed in the news accounts of military operations against Boko Haram insurgents?

2. How are the sources identified; full name, single name, alias or anonymous?

3. Were their uses of direct quotes from the news sources?

4. How often do Nigerian newspapers use sources from different sides in a story about military operations against Boko Haram?

5. Which is the dominant between military (government) sources and independent sources?

6. How often were journalists cited as sources in news reports about military operations against Boko Haram in the North East Nigeria?

\section{THEORETICAL FRAMEWORK}

The media theories that guided this study are the "agenda setting theory of the press" and "framing theory of mass communication". The agenda setting theory of the press was first introduced by McCombs and 
Shaw (1972) who evaluated the response of 100 residents of Chapel Hill, North Carolina on what they thought were the most critical and topical election issues in the US presidential election of 1968 and how that compared to what was reported by the local and national media as the most critical issues. They discovered a robust connection between what journalists and the public considered as main campaign issues. Specifically, the five most pressing campaign topics corresponded with the five most pressing campaign issues of the undecided voters that were part of the study. Based on the findings, they proposed that the press advances the public topics or agendas which are accepted by the public knowingly or unknowingly.

The general theme behind the agenda setting theory of the press is the perceived media influence on the public where news items made prominent influences the prominence of items in the public discourse, and if public talks about such issues long enough, they could result to a call for action that may be positive or negative depending on how the media has framed such issues. Carroll and McCombs (2003) distinctly describe this principle as the prominence of elements contained in news stories has an effect on the prominence of those elements among members of the general, the public. The media agenda in this study can be achieved by presenting one side of the argument or presenting a balanced argument to advance an agenda. Echoing the direction of thought of Major General Enenche who claimed a bias by the media against the Nigerian military, it is expected that majority of the sources to be cited by Nigerian newspapers in the time frame would mainly compose of sources other than the military to support the bias.

Framing theory is regarded by some scholars as the second dimension of the agenda setting theory, whereas the latter is concerned with issues, the former deals with perception; how an issue is presented and the meaning the readers imply from the text of journalistic endeavors. Framing is a quality of communication that leads others to acknowledge one understanding over another because of how the issue is projected by the press in their coverage. This involves projecting the "frames" newspapers adopt, patterns of perception, interpretation, presentation, as well as emphasis, selection and omission by reporters, editors and publishers in news articles. Framing can be traced to domains of cognitive psychology (Bartlett, 1932), and anthropology through the works of Gregory Bateson $(1955 ; 1972)$, and this has been further distilled in a number of studies (Goffman, 1974; Kahneman \& Tversky, 1979; Schön \& Rein, 1994; Gitlin, 1980; Hallahan, 1999; Rothman \& Salovey, 1997; Entman, 1993). 
For scholars in communication studies, the study of media frames are important because according to Entman (1993) a frame "is really the imprint of power-it registers the identity of actors or interests that competed to dominate the text" (p. 55). The way an article is framed can potentially influence its assimilation by the audience (Iyengar \& Kinder, 1987; Entman, 1993), propagate stereotypes in the society and is capable of creating an impression of empathy or aversion toward a group of people or their ideology (Robinson, 2002; Evans, 2010). Reporting positively about military operations and the latest gadgets to be deployed in the fight against Boko Haram can strike fear into the terrorists and dissuade new converts to the ideologies of the sect. At the other spectrum, media could also frame Boko Haram as religious ideologists who deserve the freedom to practice their brand of Islam in their region. Thus, frames can be critical in acceptance or rejection of government policies and positions as well as escalating conflicts or in conflict resolution. Therefore, this study is based on the salience of explicit frames generated by the news media organisations in their selection of news sources for reporting about military operations against Boko Haram insurgents.

Entman defines salience as "making a piece of information more noticeable, meaningful, or memorable to audience" (p.53). Thus, from the assertions of General Enenche, the media gave salience to non-military sources when reporting about military operations against Boko Haram, while omitting those of the military and government forces. Source or quote selection can be used to advance a particular narrative due to reporter's bias or editorial policy (Entman 2004; Scheufele 1999). They achieve this in news presentation by emphasis, selecting certain sources and not others and omitting sources that would negate the agenda they intend to propagate. Gitlin (1980) emphasized that journalists regularly choose among diverse approaches in the presentation of news articles. Their perception involves selecting and making prominent some aspects of events or issues, and making correlations among them in order to advance a narrative, evaluation, and/or resolution.

\section{LITERATURE REVIEW}

Reporters critique and evaluate the activities of other people and institutions, and present information about news worthy events, and what they publish can have an overwhelming influence on the people, businesses and institutions they cover, as well as society at large. Journalists are thus expected to live up to the highest standards of integrity in the course of their functions, and by integrity we infer: truth, fairness, sincer- 
ity, and avoiding the appearance of a conflict of interest when presenting news reports to readers. Journalists should seek to be fair and truthful in reporting what their sources tell them, factual accuracy entails checking, and double-checking, ensure to get as many sides of the story by interviewing multiple sources with different and often contradictory viewpoints. (Panenberg, 2007).

Ross (1946) argues that communication entails the responsibility to be truthful. He buttresses this assertion by highlighting a Kantian categorical imperative-without a commitment to truth-telling, societies fail to function. Without confidence that other parties are telling the truth-a confidence backed by consistent actions that, over time, create a positive reputation and engender trust-people may lose their ability to transfer information, to act effectively as moral agents, or to even co-exist with others. It is with this sense that the accusation of bias against the media by the Director of Defense Headquarter of the Military in Nigeria becomes troubling. As enablers of information transfer to the audience, it behooves that media information should be as accurate, honest and truthfully as good as it can be. What aids media truthfulness is how they source the information they share across their platforms.

Boeyink (1990) accentuates the significance of sourcing as a method of engendering trust when he stated thus, "attribution serves as an important truth-telling check on a reporter's accuracy. If the source of the information is provided, that information can be independently verified by others. Errors can then be more easily discovered and corrected" (p. 235). In support, Duffy and Freeman (2011) aver that offering full attribution for news sources provides an inherent promise to the reader that validates the information contained in the journalistic piece; this information provided is true and you can go ask the source if in doubt. Vultee (2010) adds to this that naming names of sources is an important aspect of newsgathering and reporting, it consistently creates reports that readers consider credible.

However, Vultee (2010) cautions that media credibility extends beyond its function as a strategic ritual associating facts-including namesinvariably with truth-telling. Rather, credibility functions as a complex ethical concept-one that is both created and earned at many levels of the process: "individual, institution, audience, context, and practice" (p. 16). It includes a responsibility to do the correct things for the public good in order to create and foster trust between the journalist and the audience and also those they are reporting about; this they can achieve by truth-telling when reporting the news in all circumstances. 
Snow-Capparelli (2013) enjoins reporters to seek out intelligent and articulate sources from all relevant perspectives and partisan viewpoints. Journalists are encouraged to seek out both those who have power and those who do not; this ensures equal representations especially of the groups under examination. In the case of our research, journalists when reporting about military operations should include statements from the military, corroborating information from the residents in the area, civil society organisations and Think-Tanks, and if possible the insurgents who received the actions of the military for their own side of how the their engagement with the military fared. Snow-Capparelli (2013) continues that journalists should avoid single-source stories when possible, most news reports should have a minimum of three sources; special reports and indepth features should contain many more.

Kovach and Rosenthiel (2007) highlight that the main role of journalists "is to provide citizens with the information they need to be free and self-governing" (p. 12). They emphasize that journalists do little good if they suppress information that can help citizens make informed decisions. Some authors (Hoyt, 2009; Panenberg, 2007; Coile, 2005; Okrent, 2004) argue that attributing information to anonymous sources may occasionally be the only way to fulfill this information provision role of the media. Duffy and Freeman (2011) opine that the ethics surrounding the use of anonymous sources involves two contending principles; the duty to inform the public versus the duty to do so truthfully and transparently. The journalist is left with making the weighty decision of these competing principle, they must weigh their decisions and interests within an ethical framework. Some of these anonymous-sourced stories have many a time put the journalist on collision course with the government (Ibekwe, 2017; Ogundipe, 2017; Abimboye, 2014; Abimboye \& Ibeh, 2014).

States are reliant on news outfits to update the public about their actions and policies. The usual standard of reporting is such that journalists cover regular beats and rely on official government spokespersons or sources for up to date information, fortifies prevailing norms and state-society relations. A symbiotic relationship is observed here where the government needs the media to create awareness for government policies and programmes, in return, journalists are granted access to officially verifiable sources of government information (Hoffman, 2006; Ngige, Badekale \& HammanJoda, 2016). The level of this cooperation is still an issue of debate among media scholars and commentators.

Hook and $\mathrm{Pu}(2006)$ citing Reese and Buckalew (1995) state that literary studies of news coverage of United States foreign policy reliably reveal patterns of news framing that legitimise the government's percep- 
tions and positions on topical issues as exemplified in the coverage of the Persian Gulf War in 1991 which was characterised by patriotic frames. The anti-corruption programmes of the Buhari-led government in Nigeria since 2015 have been widely reported by the Nigerian media especially newspapers (Tukur, 2015; Krishi \& Sule, 2016). Many times, cases involving past government officials accused of corruption are sensationally reported with anonymous government sources providing details of how such officials "allegedly" looted public monies entrusted to their care (Adesomoju, 2016; Egbas, 2016). The publicity of such corruption cases were to shore up a public support base for the government anti-corruption policy in line with the ruling party's campaign promises.

\section{MEDIA-SOURCE DYNAMICS}

Examining journalists and their sources can be traced back to questions about influence bias and the agenda being advocated by media players. Elmasry (2009) notes that the nature of the sources is thereby crucial in understanding the framing processes when studying newspaper reports by showing a preference for one point of view over another. Gauseth (2012) opines that salience can also be achieved by including viewpoints from one side of an armed conflict while excluding other actors. This means that including or excluding certain sources when reporting about a news story can have an influence on news presentation and perception of the issue under investigation. Berkowitz (2009) pertinently questions the manner the use of news sources by journalists' portrays a specific news motivation that either includes or negates some topics ahead of others. Elmasry (2009) describes this as making one perspective more prominent by allocating more to the view point and in the process legitimizes the oftenquoted side.

This exclusion or inclusion will have an effect on how the public or other actors in the issues interpret reported news stories. If the news sources for a story are particularly from one faction of events, the story is expected to be written in favour of the faction that provides the news sources. Boko Haram has often times attacked journalists attributing it to the role of journalists in presenting government side of the story and neglecting their own account of events (Reporters Without Border, 2013; Abang, 2017).

Scholars have documented the relevance of news sources and how they influence news stories and also how the choice of sources enables framing when writing reports by giving prominence to the side regularly quoted as sources (Manning, 2001; Schneider, 2011). From evidence, 
Schneider (2011) advocated that the use of sources and quotes allows reporters to beckon the expressions of different sources to construct news accounts in specific narratives to suit the agenda they are projecting based on their personal bias or house style. van Dijk (1988) contends that "quotations allow the insertion of subjective interpretation, explanations, or opinions about current news events, without breaking the ideological rule that require(s) the separation of facts from opinions" (152).

Quintessentially, the dynamic that exists between journalists and their news sources have been portrayed by scholars as a struggle for control over public perception and public approval of the sources and the agenda (McQuail, 2010; Berkowitz, 2009; Sallot \& Johnson, 2006). Berkowitz (2009) is of the view that ethics of the profession does not allow reporters to have an opinion when reporting on an event, however, their opinion could be limited to things such as describing settings, crowd size, appearance of people and what they said. Ericson (1999) earlier theorized that by following this source-driven process, journalists become society's scientists and the news they produce becomes their scientific report because they can be empirically verified to qualify as truth. However, reporting terrorism has become more difficult with prevalent cases occurring nearly in every part of the developed and developing nations.

\section{RESEARCH METHODOLOGY}

This study made use of content analysis research design. The research populations consisted of the four daily newspapers in Nigeria which were purposively selected, they include: Vanguard, Premium Times, Daily Trust, and The Nation; and all editions of the selected newspapers from January 1, 2014 to December 31, 2016 including weekend versions. This gives us 365 days in 2014 and 2015 each and 366 days in 2016 all amounting to 4384 issues in total. The sample size of this study was calculated using the Taro Yamane (Yamane, 1973) formula with a confidence level of $95 \%$. The formula is presented as follows:

$$
n=\frac{N}{1+N(e)^{2}}
$$

Where:

$\mathrm{n}=$ sample size required

$\mathrm{N}=$ number of people in the population

$\mathrm{e}=$ allowable error $(\%)$ 
Thus, substituting for the values in the equation,

This becomes,

$$
n=\frac{4384}{1+4384 \cdot(0,05)^{2}}=366 \text { (rounded up). }
$$

However, to ensure a uniform distribution of the sample sizes across the sampled newspapers, the sample size of 366 was reduced to $n=360$, quota sampling was further used to share the sample across the newspapers into 90 issues for each sampled newspaper, and further divided into 30 issues per year for evenness.

In order to select 30 issues for each year, a calendar was constructed using systematic random sampling technique with $1 / \mathrm{n}=12$, i.e. one issue was systematically selected every 12 days for all of the sampled newspapers. To reduce bias in selection of the starting point in January, a straw was drawn for numbers 1 to 12 . The number 10 was selected, thus January 102014 was chosen as the starting point for each sampling year. The unit of analysis for this study is straight news; the main method of data collection for the paper was reviews of secondary sources consisting of news reports about military operations against Boko Haram group in the period under review using both quantitative and qualitative techniques in data analysis.

The study was limited to digital versions of the sampled newspapers available on the internet for ease of retrieval and analysis. Digital versions were used because the Internet provides the technical capability for researchers to scrutinize an article, assess its sources, and communicate using channels that other media do not provide. This has been validated in a number of studies (Freyenberger, 2013; Wang \& Riffe, 2010). The primary substance in the choice of newspapers for the study was the prominence of the selected media, as manifest in their circulation and regional representation. Vanguard was the highest rated Nigerian newspaper; Premium Times was the most read online newspaper in Nigeria (Alexa, 2017), The Nation was rated as the third best newspaper in Nigeria (Chigozie, 2013) while Daily Trust was the top rated newspaper from Northern Nigeria (Shehu, 2015). The research population includes all editions of the selected newspapers from January 1, 2014 to December 31, 2016 including weekend versions. This gives us 365 days in 2014 and 2015 each and 366 days in 2016 all amounting to 4384 issues in total. 


\section{RESULTS AND DISCUSSION}

Findings from the study are presented in this section and are modeled after the research questions.

Research Question 1: What is the average number of sources observed in the news accounts?

\begin{tabular}{|c|c|c|c|c|c|c|c|}
\hline & \multirow[b]{2}{*}{$\begin{array}{l}\text { Number of } \\
\text { sources per story }\end{array}$} & \multicolumn{4}{|c|}{ Newspapers } & \multirow[b]{2}{*}{ Total } & \multirow[b]{2}{*}{$\%$} \\
\hline & & $\begin{array}{l}\text { Daily } \\
\text { Trust }\end{array}$ & $\begin{array}{l}\text { Premium } \\
\text { Times }\end{array}$ & The Nation & Vanguard & & \\
\hline 1 & Zero & 0 & 1 & 2 & 2 & 5 & 3 \\
\hline \multicolumn{2}{|c|}{2 One } & 19 & 32 & 23 & 40 & 114 & 61.5 \\
\hline 3 & Two & 3 & 12 & 9 & 16 & 40 & 22 \\
\hline \multicolumn{2}{|c|}{4 Three } & 3 & 6 & 5 & 3 & 17 & 9 \\
\hline 5 & Four & 0 & 3 & 4 & 1 & 8 & 4 \\
\hline \multirow[t]{2}{*}{6} & Five or more & 1 & 0 & 0 & 0 & 1 & 0.5 \\
\hline & Total & 26 & 54 & 43 & 62 & 185 & 100 \\
\hline \multicolumn{2}{|r|}{ Average } & 1.5 & 1.6 & 1.7 & 1.3 & & \\
\hline
\end{tabular}

Table 1: Number of sources in each story

The findings from Table 1 highlights that the four newspapers used a fairly similar number of sources for news stories with an average of 1.5 sources per story. The table further showed that $61.5 \%$ of the stories were written with only one source. This is against the recommendation of Snow-Capparelli (2013) that journalists should avoid single-source stories when possible, and should use a minimum of three sources, while special reports and in-depth features should contain many more. For journalists to be fair and objective, using multiple sources increases the credibility of the story. Panenberg (2007) enjoined that interviewing multiple sources with different viewpoints increases factual accuracy which entails checking, and double-checking on every piece of information before publication. On the part of newspapers reporting military operations against Boko Haram insurgents, they are enjoined to increase the number of sources for their stories as the average of 1.5 per story is half the recommended number by Snow-Capparelli (2013).

Research Question 2: How are the sources identified; full name, single name, alias or anonymous? 
How the sources were identified was presented in Table 2. It highlights that in most of the reported news about military operations against Boko Haram, $69 \%$ of the sources were identified by their full names. Worthy of mention is the fact that in 5 out of the 185 stories analyzed across the newspapers, there were no sources mentioned in the stories. The stories were written as if they were common knowledge, or the reader is left to assume either the journalist is supposed to know of the information. The journalists made no effort to identify how they got the information being reported; whether from the military, residents, civil society organisations, other media or from the web. Boeyink (1990) earlier opined that " $f$ the source of the information is provided, that information can be independently verified by others. Errors can then be more easily discovered and corrected" (p. 235).

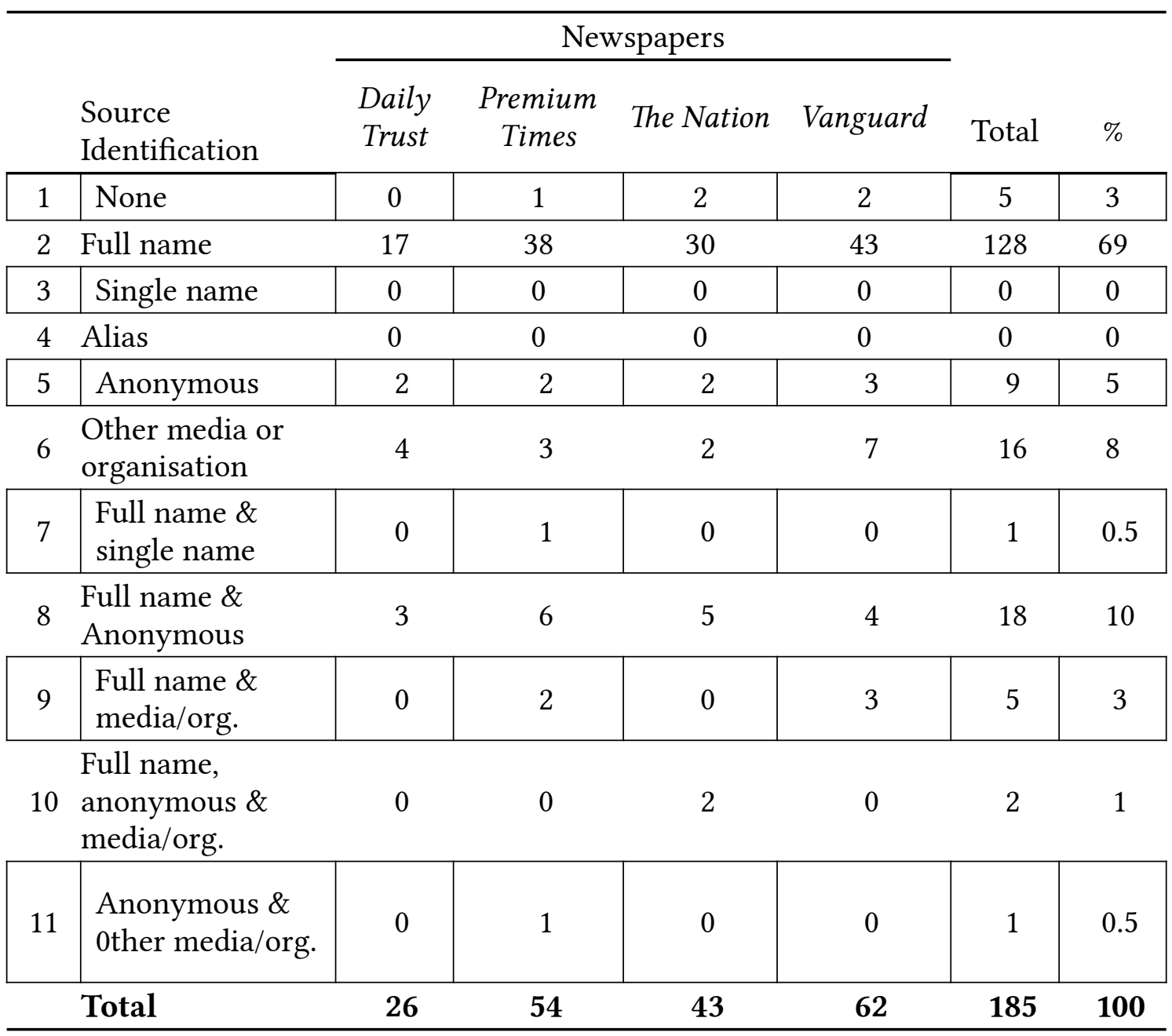

Table 2: How sources were identified in news 
Recall that Vultee (2010) stated that naming names of sources is an important aspect of newsgathering and reporting, it consistently creates reports that readers consider credible. The newspapers in this regard presented most of their stories with full attrition that identifies the sources of the information they were reporting on. Duffy and Freeman (2011) averred that offering full attribution for news sources provides an inherent promise to the reader that validates the information contained in the journalistic piece; this information provided is true and you can go ask the source if in doubt. Snow-Capparelli (2013) adds that motives of the anonymous sources should be evaluated, and they should only be used where necessary, and when used, the information provided should be corroborated with other sources.

Research Question 3: Were their use of direct quotes from the news sources?

\begin{tabular}{|c|c|c|c|c|c|c|c|}
\hline \multirow{2}{*}{\multicolumn{2}{|c|}{ Use of Quote }} & \multicolumn{4}{|c|}{ Newspapers } & \multirow[b]{2}{*}{ Total } & \multirow[b]{2}{*}{$\%$} \\
\hline & & $\begin{array}{l}\text { Daily } \\
\text { Trust }\end{array}$ & $\begin{array}{l}\text { Premium } \\
\text { Times }\end{array}$ & The Nation & Vanguard & & \\
\hline 1 & Yes & 22 & 50 & 39 & 56 & 167 & 90 \\
\hline \multirow[t]{2}{*}{2} & No & 4 & 4 & 4 & 6 & 18 & 10 \\
\hline & Total & 26 & 54 & 43 & 62 & 185 & 100 \\
\hline
\end{tabular}

Table 3: Use of Quotes in News

Quotes were prominently used in news reporting about military operations against Boko Haram in Nigeria with $90 \%$ of the news (see Table 3). This was also consistent with the results from Table 2 where most of the news stories had sources that were identified either by their full names, or in combination with anonymous sources. However, it was observed that quotes were used in stories with anonymous sources in the newspapers analyzed; Daily Trust in four of the stories where anonymous sources used quotes, the one of the stories was about the attack of Gwoza residents by Soldiers looking for escaped Boko Haram insurgent in a report on October 13, 2014 and another a story on 6th November, 2014 about an Airforce jet striking a military camp mistaking it for a Boko Haram camp. Premium Times had five such stories; The Nation and Vanguard each had six stories with similar use of quotes for anonymous sources.

Because quote selection can be used to advance a particular narrative due to reporter's bias or editorial policy (Entman 2004; Scheufele 1999), it 
is expedient for journalists to avoid using quotes for stories with anonymous sources or sources that are not properly identified in case corroboration is needed or follow up questions to verify aspects of the information they provided. The choice of sources enables framing when writing reports by giving prominence to the side regularly quoted as sources (Manning, 2001; Schneider, 2011), thus the side regularly used as sources and quoted in the news will have the narrative framed in their construct because journalists have given them a foothold in the control, dissemination and the slant introduced in reportage..

Research Question 4: How often do Nigerian newspapers use sources from different sides in a story about military operations against Boko Haram?

\begin{tabular}{|c|c|c|c|c|c|c|}
\hline \multirow[b]{2}{*}{$\begin{array}{l}\text { Use of same } \\
\text { sources }\end{array}$} & \multicolumn{4}{|c|}{ Newspapers } & \multirow[b]{2}{*}{ Total } & \multirow[b]{2}{*}{$\%$} \\
\hline & $\begin{array}{l}\text { Daily } \\
\text { Trust }\end{array}$ & $\begin{array}{l}\text { Premium } \\
\text { Times }\end{array}$ & The Nation & Vanguard & & \\
\hline 1 Yes & 25 & 47 & 41 & 58 & 171 & 92 \\
\hline $2 \mathrm{No}$ & 1 & 7 & 2 & 4 & 14 & 8 \\
\hline Total & 26 & 54 & 43 & 62 & 185 & 100 \\
\hline
\end{tabular}

Table 4: Use of varying sources in same news article

In presenting varying sources for each story analyzed in Table 4, it was discovered that $92 \%$ of the stories contained sources from the same side of the conflict. This does not enhance the credibility of the story being reported. In the fight against Boko Haram insurgents, the effect is felt by three main groups, the military, Boko Haram members and the residents of North East Nigeria. Every story for the sake of credibility should contain input from at least two of the groups to provide some sort of balance; ideally, all three should be present in every news report. But due to the issue of timeliness and access, having two can suffice for each story. Premium Times had the most varying sources for its stories with $13 \%$ of its stories compared to the other three who all had less than $7 \%$.

Snow-Capparelli (2013) enjoined reporters to seek out intelligent and articulate sources from all relevant perspectives and partisan viewpoints. 
Journalists are encouraged to seek out both those who have power and those who do not; this ensures equal representations especially of the groups under examination. In this case, the statement from military authorities or Boko Haram insurgents should not be taken on face value, efforts should be made to corroborate such information from other groups such as residents, civil society organisations who operate in the area and also other journalists for consistency and veracity of what is being reported.

Research Question 5: Which is the dominant between military (government) sources and independent sources?

\begin{tabular}{|c|c|c|c|c|c|c|}
\hline \multirow[b]{2}{*}{ Source Type } & \multicolumn{4}{|c|}{ Newspapers } & \multirow[b]{2}{*}{ Total } & \multirow[b]{2}{*}{$\%$} \\
\hline & $\begin{array}{l}\text { Daily } \\
\text { Trust }\end{array}$ & $\begin{array}{l}\text { Premium } \\
\text { Times }\end{array}$ & $\begin{array}{l}\text { The } \\
\text { Nation }\end{array}$ & Vanguard & & \\
\hline 1 No Source mentioned & 0 & 1 & 2 & 2 & 5 & 3 \\
\hline 2 Military sources only & 17 & 42 & 31 & 43 & 133 & 72 \\
\hline 3 Other sources only & 7 & 7 & 3 & 8 & 25 & 13.5 \\
\hline $4 \begin{array}{l}\text { Military and other } \\
\text { sources }\end{array}$ & 2 & 4 & 6 & 9 & 21 & 11 \\
\hline 5 Journalists only & 0 & 0 & 0 & 0 & 0 & 0 \\
\hline 6 Journalists \& Military & 0 & 0 & 1 & 0 & 1 & 0.5 \\
\hline $\begin{array}{l}7 \begin{array}{l}\text { Journalists \& other } \\
\text { sources }\end{array}\end{array}$ & 0 & 0 & 0 & 0 & 0 & 0 \\
\hline $\begin{array}{l}8 \begin{array}{l}\text { Journalists, Military \& } \\
\text { other sources }\end{array} \\
\end{array}$ & 0 & 0 & 0 & 0 & 0 & 0 \\
\hline Total & 26 & 54 & 43 & 62 & 185 & 100 \\
\hline
\end{tabular}

Table 5: Types of sources

Data from Table 5 show that $72 \%$ of the news articles used "military sources only"; adding the other categories where military sources were also used sums up to $84 \%$ of the news where the military were mentioned as sources compared to independent sources which were $25 \%$. In effect, the military were the main producers of news as against what the Sidle Commission was set out to combat in 1984. The Commission agreed that the military should not report about its own activities and it would be best the independent media do the reporting of the conduct of military activities so the public, congress and the press can make their own deductions from the news reports. An independent appraisal of the war against Boko Haram would lead to objective and critical reporting that would identify lapses sometimes before they cause damage as the information 
would be public before the National Assembly and the public purview. It conforms with the adage that a problem shared is a problem half solved.

Entman (1993) was of the view that a frame "is really the imprint of power-it registers the identity of actors or interests that competed to dominate the text" (p. 55). Thus, the military as the main sources have dominated the text about reporting military activities against Boko Haram. The way articles will be framed around the dominant interest can potentially influence its assimilation (Iyengar \& Kinder, 1987), this also buttresses the views expressed by Carroll and McCombs (2003) who opine that the prominence of elements in the news influences the prominence of those elements among the public. Reality check however sets in whenever the insurgent group carries out one of its dastardly acts such as the kidnap of the Dapchi school girls in Yobe State, Nigeria, 4 years after the kidnap of hundreds of school girls from Chibok Town, Borno State (John, 2018) or the attack of military bases by Boko Haram in leading to heavy casualties (Ilo, 2018).

Another dimension to the dominant use of military sources in news reporting about military operations against Boko Haram is the symbiotic relationship observed between the government and the press; here the government needs the media to create awareness for government policies and programmes, in return, journalists are granted access to officially verifiable sources of government information (Hoffman, 2006; Ngige, Badekale \& HammanJoda, 2016). The military thus makes available to the press information of its activities which the press are expected to share to the public to ease fears and let the people know government is in control, this ideology tends towards development communication, where information is disseminated for societal good.

Research Question 6: How often were journalists cited as sources in news reports about military operations against Boko Haram in the North East Nigeria?

From Table 5, journalists were seen as sources in one news article from The Nation, this means that journalists were not close to areas where military operations occur. Most of the reports were from military briefs, releases and interviews, other media organisations, press release by international agencies, and interviews with residents. The findings also highlight the distance in working relationship between the military and the press; this, however, needs more research to validate.

This observation corroborates earlier authors who noted the frosty relationship that exists between journalists and soldiers (Musa, 2013; Adebanwi, 2011; Odogwu, 1990). This difficulty in creating an enabling working environment may be the reason why they both find it difficult to work 
together as the nation looks to resolve the Boko Haram insurgency. Nigeria may have to borrow a leaf from the US where the Sidle Commission (1984) report was set up to work out modalities that will guide media involvement in military operations to foster transparency and accountability, both fundamental to the deepening of democracy.

The implications of the findings include that the military were both the actors and reporters of the events. With the military being the dominant sources, the stories are expected to be favourable to the military as they will not be expected to speak ill of the organisation they represent or put out information capable of damaging the reputation of the military. Gauseth (2012) reechoes that salience can also be achieved by including viewpoints from one side of an armed conflict while excluding other actors. This means that including or excluding certain sources when reporting about a news story can have an influence on news presentation and perception of the issue under investigation.

\section{CONCLUSION}

In looking at the variables investigated in this study that empirically explored the statement by the Director of Information, Defense Headquarters, Major General John Enenche, who claimed that Nigerian troops were reluctant in the past to engage the Boko Haram terrorists because the media framed the Boko Haram group as superior and winning the battle against the military making Nigerian soldiers hesitant to engage members of the sect in open battles. This view, however, is subjective; one of the ways it can be examined is by identifying the news sources contained in newspaper reports about military operations against Boko Haram insurgents. The idea being that if there are less military sources quoted and cited in reports, it increases the likelihood of media bias against the military. On the other hand, if there are more of military sources, it reduces the likelihood of media bias as the military is not expected to speak bad about their own organisation.

Finally, the findings do not support the statement by Major General Enenche that the media were responsible for soldiers abandoning the battlefield when confronted by Boko Haram insurgents. Instead, the media have pandered towards the military by ensuring that most of the sources for news about military incursions against the group are military sources and at a great cost to journalistic integrity as there was no evidence of journalists being given first hand access to information on military operations, or being embedded with the military nor specific evidence of journalists being granted access to flashpoint areas. The study 
recommends further research into the dynamics of the relationship between the media and military in order to have an insight into the cooperation between them to foster openness and accountability in military activities.

\section{References}

Abang, M. (2017). A tale of resilience: Journalists working under the veil of Boko Haram. Sahara Reporters. Retrieved from www.saharareporters.com/2017/01/14/ tale-resilience-journalists-working-under-veil-boko-haram

Abimboye, M. (2014, June 7). Nigerian military goes berserk, blocks newspapers distribution in Abuja, Lagos. . Premium Times. Retrieved from https://www.premiumtimesng.com/news/162 255-nigerian-military-goes-berserk-blocks-newspapers-distribution-abuja-lagos.html

Abimboye, M. \& Ibeh, N. (2014, June 6). Nigerian military defends attack on Newspapers, describes it as "routine security action." Premium Times. Retrieved from https://www.premiumtimesng.com/news/162 205-nigerian-military-defendsattack-newspapers-describes-routine-security-action.html

Adebanwi, W. (2011). The radical press and security agencies in Nigeria: Beyond hegemonic polarities. African Studies Review, 54 (3), 45-69.

Adesomoju, A. (2016, October 17). Arrested judges: Lawyer sues Buhari, DSS, AGF, others for N50bn. The Punch. Retrieved from http://punchng.com/arrestedjudges-lawyer-sues-buhari-dss-agf-others-n50bn-2/

Alexa (2017). The top 500 sites on the web. Retrieved from http://www.alexa.com/topsites/category/Top/Regional/Africa/Nigeria/ News and Media/Newspapers

Bartlett, F. C. (1932). Remembering: A study in experimental and social psychology. Cambridge, U.K.: Cambridge University Press.

Bateson, G. (1972). A theory of play and phantasy: Steps to an ecology of the mind. New York: Ballantine Books.

Berkowitz, D. A. (2009). Reporters and their sources. In K. Wahl-Jorgensen \& T. Hanitzsch (Eds.), The handbook of Journalism Studies (pp. 102-115). New York, NY: Routledge

Boeyink, D. E. (1990). Anonymous sources in news stories: Justifying exceptions and limiting abuses. Journal of Mass Media Ethics, 5(4), 233-246. Doi: 10.1207/ s15327 728jmme0504_2

Carroll, C. \& McCombs, M. (2003). Agenda setting effects of business news on the public's images and opinions about major corporations'. Corporate Reputation Review, 6, 36-46. Doi: 10.1057/palgrave.crr.1540188

Chigozie, E. (2013). Top 10 Nigerian newspapers (most read online). Retrieved from https://answersafrica.com/top-10-nigerian-newspapers-most-read-online.html 
Coile, Z. (2005, June 1). Watergate case shows value of anonymous sources. San Francisco Chronicle. Retrieved from http://articles.sfgate.com/2005-06-01/news/ 173768641 guantanamo-bay-sources-journalism

Duffy, M. J. \& Freeman, C. P. (2011). Unnamed Sources: A Utilitarian Exploration of their Justification and Guidelines for Limited Use. Fournal of Mass Media Ethics, 26(4), 297-315. Doi: 10.1080/08900 523.2011.606006

Egbas, J. (2016, October 17). How President ordered DSS to arrest more judges as soon as he returned home. The Pulse. Retrieved from http://www.pulse.ng/local/buhari-how-president-ordered-dss-to-arrest-morejudges-as-soon-as-he-returned-home-id5 619396.html

Elmasry, M. (2009). Death in the Middle East: An analysis of how the New York Times and Chicago Tribune framed killings in the second Palestinian Intifada. Fournal of Middle East Media, 5(1), 1-46.

Entman, R. M. (1993). Framing: Toward clarification of a fractured paradigm. fournal of Communication, 43(4), 51-58.

Entman, R. M. (2004). Projections of power: Framing news, public opinion and US Foreign policy. Chicago: Chicago University Press.

Ericson, R. (1999). How journalists visualize fact. The Annals of the American Academy of Political and Social Science, 560(1), 83-95.

Erunke, J. (2017, March 16). Boko Haram: Why troops were refusing to go to battle front - DHQ. Vanguard. Retrieved from http://www.vanguardngr.com/2017/03/ boko-haram-troops-refusing-go-battle-front-dhq/

Evans, M. (2010). Framing international conflicts: Media coverage of fighting in the Middle East. International fournal of Media \& Cultural Politics, 6(2), 209-233. Doi: 10.1386/mcp.6.2.209_1

Gauseth, D. (2012). Framing the Russia-Georgian War: An analysis of the Norwegian print-press coverage in August 2008. Master's thesis submitted to the department of History and Classical Studies, Norwegian University of Science and Technology, Trondheim, Norway.

Gitlin, T. (1980). The whole world is watching. Berkeley: University of California Press.

Goffman, E. (1974). Frame analysis: An essay on the organization of experience. Cambridge: Harvard University Press.

Hallahan, K. (1999). Seven models of framing: Implications for Public Relations. Journal of Public Relations Research, 11(3), 205-242. Doi: 10.1207/ s1532754xjprr1103_02

Hoffman, B. (2006). Inside terrorism. New York: Columbia University Press.

Hook, S. W. \& Pu, X. (2006). Framing Sino-American relations under stress: A reexamination of news coverage of the 2001 spy plane crisis. Asian Affairs, 33(3), 167183. Doi: $10.3200 /$ AAFS.33.3.167-183

Hoyt, C. (2009a, March 22). Those persistent anonymous sources. The New York Times. Retrieved from http://www.nytimes.com/2009/03/22/opinion/22pubed.html 
Ibekwe, N. (2017, January 24). Nigerian Army Vows To Charge PREMIUM TIMES For 'Fraudulently Obtaining' Military Information. Sahara Reporters. Retrieved from http://saharareporters.com/2017/01/24/nigerian-army-vows-charge-premiumtimes-\%E2\%80\%98fraudulently-obtaining $\% \mathrm{E} 2 \% 80 \% 99$-military-information

Iyengar, S. \& Kinder, D. R. (1987). News that matters. Chicago: University of Chicago press.

Kahneman, D., \& Tversky, A. (1979). Prospect theory: An analysis of decision under risk. Econometrica, 47, 263-291. Doi: 10.2307/1914185

Kovach, B., \& Rosenstiel, T. (2007). The elements of journalism: What newspeople should know and the public should expect. New York: Three Rivers Press.

Krishi, M. A. \& Sule, I. M. (2016, May 6). \$40m: Jonathan’s cousin petitions Reps over EFCC arrest. Daily Trust. Retrieved from htpps://www.dailytrust.com.ng/news/ general/-40m-jonathan-s-cousin-petitions-reps-over-efcc-arrest/145 638

Lippmann, Walter (1922). Public opinion. New York: Macmillan.

Lister, G. (2001). The pursuit of truth can be elusive in Africa: Independent journalists are branded unpatriotic and anti-government. In B. Giles (Ed.). The Elements of Journalism (p.11), 55(2). Neiman Reports: The Neiman Foundation for Journalism at Harvard University

Manning, P. (2001). News and news sources: A critical introduction. London: Sage.

McCombs, M.E., \& D.L. Shaw. (1972). The agenda-setting function of mass media. Public Opinion Quarterly, 36(2), 176-87. Doi: 10.1086/267990

Mcquail, D. (2010). Mass Communication Theory (6th ed.). London: Sage Publications.

Musa, S. (2013). Improving media-military relationship in Nigeria. Sahara Reporters. Retrieved from www.saharareporters.com/2013/02/18/improving-mediamilitary-relationship-nigeria-lt-sagir-musa

Ngige C. V., Badekale, A. F. \& HammanJoda I., (2016). The media and Boko Haram insurgency in Nigeria: A content analysis and review. International fournal of Peace and Conflict Studies, 3(1), 58-65.

Odogwu, A. (1990). Public relations practice: A case study of the Nigerian army. Thesis submitted to the Public Relations Department, University of Nigeria, Nsukka.

Ogundipe, S. (2017, January 19). Nigerian Police detain Premium Times publisher, journalist on 'orders from above'. Premium Times. Retrieved from http://www.premiumtimesng.com/news/headlines/221 029-nigerian-police-detain-premium-times-publisher-journalist-orders.html

Okrent, D. (2004, May 30). Weapons of mass destruction? Or mass distraction? The New York Times. Retrieved from http://www.nytimes.com/2004/05/30/weekinreview/the-public-editor-weaponsof-mass-destruction-or-mass-distraction.html.

Panenberg, A. L. (2007). NYU Journalism handbook for students: Ethics, law and good practice. Department of Journalism, New York University, Creative Commons: New York. 
Reporters Without Border (2013). Predators of the Press Freedom 2013. Paris: Reporters Without Borders.

Robinson, P. (2002). The CNN effect: The myth of news, foreign policy and intervention. London: Routledge.

Ross, W. D. (1946). The Right and the Good. Oxford: Clarendon Press.

Rothman, A. J., \& Salovey, P. (1997). Shaping perceptions to motivate healthy behavior: The role of message framing. Psychological Bulletin, 121(1), 3-19.

Sallot, L., \& Johnson, E. (2006). Investigating relationships between journalists and public relations practitioners: Working together to set, frame and build the public agenda, 1991-2004. Public Relations Review, 32, 151-159. Doi: 10.1016/j.pubrev.2006.02.008

Scheufele, D. A. (1999). Framing as a theory of media effects. Fournal of Communication, 49(1), 103-122. Doi: 10.1111/j.1460-2466.1999.tb02 784.x

Schneider, B. (2011). Sourcing homelessness: How journalists use sources to frame homelessness. Fournalism, 13(1), 71-86. Doi: 10.1177/1464884911421573

Schon, D. A., \& Rein, M. (1994). Frame reflection: Towards the resolution of intractable policy controversies. New York: Basic Books.

Sidle,W. (1984). Sidle Commission report on the Media and the Military. Office of Assistant Secretary of Defense (Public Affairs), Washington D.C.

Snow-Capparelli, S. (2013). Journalism Code of Ethics and Professional Practices. Mount Royal Journalism Program, Faculty of Communication Studies, Calgary Journal Connect.

Tukur, S. (2015, December 1). \$2.2billion arms deal: Why EFCC arrested Dokpesi, exGovernor Bafarawa. Premium Times. Retrieved from www.premiumtimesng.com/news/headlines/194241-2-2billion-arms-deal-whyefcc-arrested-dokpesi-ex-governor-bafarawa.html

van Dijk, T. A. (1988). News as discourse. New Jersey: Lawrence Erlbaum Associates.

Vultee, F. (2010). Securitization. Journalism Practice, 4(1), 33-47. Doi: 10.1080/17512780903172049

Wang, X. \& Riffe, D. (2010). An exploration of sample sizes for content analysis of the New York Times web site. Web Journal of Mass Communication Research, 20. Retrieved from htpps://www.scripps.ohiou.edu/wjmcr/vol20

Yamane, T. (1973). Statistics: An introductory analysis. New York: Harper and Row.

Список литературы

Abang, M. (2017). A tale of resilience: Journalists working under the veil of Boko Haram. Sahara Reporters. Retrieved from www.saharareporters.com/2017/01/14/ tale-resilience-journalists-working-under-veil-boko-haram 
Abimboye, M. (2014, June 7). Nigerian military goes berserk, blocks newspapers distribution in Abuja, Lagos. . Premium Times. Retrieved from https://www.premiumtimesng.com/news/162 255-nigerian-military-goes-berserk-blocks-newspapers-distribution-abuja-lagos.html

Abimboye, M. \& Ibeh, N. (2014, June 6). Nigerian military defends attack on Newspapers, describes it as "routine security action." Premium Times. Retrieved from https://www.premiumtimesng.com/news/162 205-nigerian-military-defendsattack-newspapers-describes-routine-security-action.html

Adebanwi, W. (2011). The radical press and security agencies in Nigeria: Beyond hegemonic polarities. African Studies Review, 54 (3), 45-69.

Adesomoju, A. (2016, October 17). Arrested judges: Lawyer sues Buhari, DSS, AGF, others for N50bn. The Punch. Retrieved from http://punchng.com/arrestedjudges-lawyer-sues-buhari-dss-agf-others-n50bn-2/

Alexa (2017). The top 500 sites on the web. Retrieved from http://www.alexa.com/topsites/category/Top/Regional/Africa/Nigeria/ News and Media/Newspapers

Bartlett, F. C. (1932). Remembering: A study in experimental and social psychology. Cambridge, U.K.: Cambridge University Press.

Bateson, G. (1972). A theory of play and phantasy: Steps to an ecology of the mind. New York: Ballantine Books.

Berkowitz, D. A. (2009). Reporters and their sources. In K. Wahl-Jorgensen \& T. Hanitzsch (Eds.), The handbook of Journalism Studies (pp. 102-115). New York, NY: Routledge

Boeyink, D. E. (1990). Anonymous sources in news stories: Justifying exceptions and limiting abuses. Fournal of Mass Media Ethics, 5(4), 233-246. Doi: 10.1207/ s15327 728jmme0504_2

Carroll, C. \& McCombs, M. (2003). Agenda setting effects of business news on the public's images and opinions about major corporations'. Corporate Reputation Review, 6, 36-46. Doi: 10.1057/palgrave.crr.1540188

Chigozie, E. (2013). Top 10 Nigerian newspapers (most read online). Retrieved from https://answersafrica.com/top-10-nigerian-newspapers-most-read-online.html

Coile, Z. (2005, June 1). Watergate case shows value of anonymous sources. San Francisco Chronicle. Retrieved from http://articles.sfgate.com/2005-06-01/news/ 173768641 guantanamo-bay-sources-journalism

Duffy, M. J. \& Freeman, C. P. (2011). Unnamed Sources: A Utilitarian Exploration of their Justification and Guidelines for Limited Use. Fournal of Mass Media Ethics, 26(4), 297-315. Doi: 10.1080/08 900 523.2011.606006

Egbas, J. (2016, October 17). How President ordered DSS to arrest more judges as soon as he returned home. The Pulse. Retrieved from http://www.pulse.ng/local/buhari-how-president-ordered-dss-to-arrest-morejudges-as-soon-as-he-returned-home-id5 619396.html 
Elmasry, M. (2009). Death in the Middle East: An analysis of how the New York Times and Chicago Tribune framed killings in the second Palestinian Intifada. Fournal of Middle East Media, 5(1), 1-46.

Entman, R. M. (1993). Framing: Toward clarification of a fractured paradigm. fournal of Communication, 43(4), 51-58.

Entman, R. M. (2004). Projections of power: Framing news, public opinion and US Foreign policy. Chicago: Chicago University Press.

Ericson, R. (1999). How journalists visualize fact. The Annals of the American Academy of Political and Social Science, 560(1), 83-95.

Erunke, J. (2017, March 16). Boko Haram: Why troops were refusing to go to battle front - DHQ. Vanguard. Retrieved from http://www.vanguardngr.com/2017/03/ boko-haram-troops-refusing-go-battle-front-dhq/

Evans, M. (2010). Framing international conflicts: Media coverage of fighting in the Middle East. International fournal of Media \& Cultural Politics, 6(2), 209-233. Doi: $10.1386 /$ mcp.6.2.209_1

Gauseth, D. (2012). Framing the Russia-Georgian War: An analysis of the Norwegian print-press coverage in August 2008. Master's thesis submitted to the department of History and Classical Studies, Norwegian University of Science and Technology, Trondheim, Norway.

Gitlin, T. (1980). The whole world is watching. Berkeley: University of California Press.

Goffman, E. (1974). Frame analysis: An essay on the organization of experience. Cambridge: Harvard University Press.

Hallahan, K. (1999). Seven models of framing: Implications for Public Relations. Journal of Public Relations Research, 11(3), 205-242. Doi: 10.1207/ s1 532754xjprr1103_02

Hoffman, B. (2006). Inside terrorism. New York: Columbia University Press.

Hook, S. W. \& Pu, X. (2006). Framing Sino-American relations under stress: A reexamination of news coverage of the 2001 spy plane crisis. Asian Affairs, 33(3), 167183. Doi: $10.3200 /$ AAFS.33.3.167-183

Hoyt, C. (2009a, March 22). Those persistent anonymous sources. The New York Times. Retrieved from http://www.nytimes.com/2009/03/22/opinion/22pubed.html

Ibekwe, N. (2017, January 24). Nigerian Army Vows To Charge PREMIUM TIMES For 'Fraudulently Obtaining' Military Information. Sahara Reporters. Retrieved from http://saharareporters.com/2017/01/24/nigerian-army-vows-charge-premiumtimes-\%E2\%80\%98fraudulently-obtaining $\% \mathrm{E} 2 \% 80 \% 99$-military-information

Iyengar, S. \& Kinder, D. R. (1987). News that matters. Chicago: University of Chicago press.

Kahneman, D., \& Tversky, A. (1979). Prospect theory: An analysis of decision under risk. Econometrica, 47, 263-291. Doi: 10.2307/1914185

Kovach, B., \& Rosenstiel, T. (2007). The elements of journalism: What newspeople should know and the public should expect. New York: Three Rivers Press. 
Krishi, M. A. \& Sule, I. M. (2016, May 6). \$40m: Jonathan’s cousin petitions Reps over EFCC arrest. Daily Trust. Retrieved from htpps://www.dailytrust.com.ng/news/ general/-40m-jonathan-s-cousin-petitions-reps-over-efcc-arrest/145 638

Lippmann, Walter (1922). Public opinion. New York: Macmillan.

Lister, G. (2001). The pursuit of truth can be elusive in Africa: Independent journalists are branded unpatriotic and anti-government. In B. Giles (Ed.). The Elements of fournalism (p.11), 55(2). Neiman Reports: The Neiman Foundation for Journalism at Harvard University

Manning, P. (2001). News and news sources: A critical introduction. London: Sage.

McCombs, M.E., \& D.L. Shaw. (1972). The agenda-setting function of mass media. Public Opinion Quarterly, 36(2), 176-87. Doi: 10.1086/267 990

Mcquail, D. (2010). Mass Communication Theory (6th ed.). London: Sage Publications.

Musa, S. (2013). Improving media-military relationship in Nigeria. Sahara Reporters. Retrieved from www.saharareporters.com/2013/02/18/improving-mediamilitary-relationship-nigeria-lt-sagir-musa

Ngige C. V., Badekale, A. F. \& HammanJoda I., (2016). The media and Boko Haram insurgency in Nigeria: A content analysis and review. International fournal of Peace and Conflict Studies, 3(1), 58-65.

Odogwu, A. (1990). Public relations practice: A case study of the Nigerian army. Thesis submitted to the Public Relations Department, University of Nigeria, Nsukka.

Ogundipe, S. (2017, January 19). Nigerian Police detain Premium Times publisher, journalist on 'orders from above'. Premium Times. Retrieved from http://www.premiumtimesng.com/news/headlines/221 029-nigerian-police-detain-premium-times-publisher-journalist-orders.html

Okrent, D. (2004, May 30). Weapons of mass destruction? Or mass distraction? The New York Times. Retrieved from http://www.nytimes.com/2004/05/30/weekinreview/the-public-editor-weaponsof-mass-destruction-or-mass-distraction.html.

Panenberg, A. L. (2007). NYU Journalism handbook for students: Ethics, law and good practice. Department of Journalism, New York University, Creative Commons: New York.

Reporters Without Border (2013). Predators of the Press Freedom 2013. Paris: Reporters Without Borders.

Robinson, P. (2002). The CNN effect: The myth of news, foreign policy and intervention. London: Routledge.

Ross, W. D. (1946). The Right and the Good. Oxford: Clarendon Press.

Rothman, A. J., \& Salovey, P. (1997). Shaping perceptions to motivate healthy behavior: The role of message framing. Psychological Bulletin, 121(1), 3-19.

Sallot, L., \& Johnson, E. (2006). Investigating relationships between journalists and public relations practitioners: Working together to set, frame and build the public agenda, 1991-2004. Public Relations Review, 32, 151-159. Doi: 10.1016/j.pubrev.2006.02.008 
Scheufele, D. A. (1999). Framing as a theory of media effects. Fournal of Communication, 49(1), 103-122. Doi: 10.1111/j.1460-2466.1999.tb02 784.x

Schneider, B. (2011). Sourcing homelessness: How journalists use sources to frame homelessness. Fournalism, 13(1), 71-86. Doi: 10.1177/1464884911421573

Schon, D. A., \& Rein, M. (1994). Frame reflection: Towards the resolution of intractable policy controversies. New York: Basic Books.

Sidle,W. (1984). Sidle Commission report on the Media and the Military. Office of Assistant Secretary of Defense (Public Affairs), Washington D.C.

Snow-Capparelli, S. (2013). Journalism Code of Ethics and Professional Practices. Mount Royal Journalism Program, Faculty of Communication Studies, Calgary Journal Connect.

Tukur, S. (2015, December 1). \$2.2billion arms deal: Why EFCC arrested Dokpesi, exGovernor Bafarawa. Premium Times. Retrieved from www.premiumtimesng.com/news/headlines/194241-2-2billion-arms-deal-whyefcc-arrested-dokpesi-ex-governor-bafarawa.html

van Dijk, T. A. (1988). News as discourse. New Jersey: Lawrence Erlbaum Associates.

Vultee, F. (2010). Securitization. Fournalism Practice, 4(1), 33-47. Doi: 10.1080/17512780903172049

Wang, X. \& Riffe, D. (2010). An exploration of sample sizes for content analysis of the New York Times web site. Web Journal of Mass Communication Research, 20. Retrieved from htpps://www.scripps.ohiou.edu/wjmcr/vol20

Yamane, T. (1973). Statistics: An introductory analysis. New York: Harper and Row. 